\title{
Kapitalist Gelişim İçinde Samsun Köylüsü: Bir Alan Araştırmasının Gösterdikleri*
}

\section{Peasantry in Samsun During the Development of Capitalism: The Results of a Field Study}

\author{
Ezgi TURMUŞ BINICi ${ }^{1}$ (i)
}

\section{öz}

Küresel kapitalizmin etkisi dünya genelinde köylülüğü derinden etkilerken, Türkiye'de de bu süreç benzer bir şekilde köylülüğü giderek tasfiye koşullarına sürüklemektedir. Endüstriyel tarımla birlikte artan ekolojik problemler ve gıda sorunu gün geçtikçe daha görünür hale gelirken köylülük ve üretimi yeniden güncelliğini koruyan bir tartışma alanı yaratmaktadır. Türkiye'nin halâ görece sahip olduğu köylü nüfusu bu nedenle tartışmayı ülke açısından güncel tutmanın da önemine işaret etmektedir. Samsun ise bu tartışmanın yürütülebilmesi açısından sahip olduğu özelliklerle önemli bir örnek olarak karşımıza çıkıyor. Çalışma büyük köy nüfusu ve yüksek tarımsal potansiyeli ile Samsun köylüsünü ele alırken kapitalist dönüşüm içerisinde topraktan pazara artan bağımlıı̆ın etkilerini köylerde yapılan alan araştırmasına dayanarak değerlendirmektedir. Köylülerle yapılan görüşmelerde mülkiyet, tarımsal destekleme, üretim, borçlanma, hane emeğindeki değişim, devlet-köylü ilişkisi üzerinden belirginleşen sorun alanları ortaya konmakta, köylülerin güncel durumuna ve algılarına dair bir değerlendirme yapılmaktadır. Samsun'da genel tablo zayıflayan tarımsal üretime işaret ederken, köy nüfusundaki dramatik düşüş ve göç, kentin geçmişten bugüne getirdiği tarımsal üretim özelliklerinin de değişimini göstermektedir. Çalışma tüm bu sorun alanları çerçevesinde uygulanan politikaların etkisini ve kapsayıcılığını tartışmaya açmayı hedeflemektedir.

Anahtar kelimeler: Köylülük, Tarım sorunu, Küresel kapitalizm JEL Sınıflaması: Q10, Q18, P18

\section{ABSTRACT}

The influence of global capitalism throughout the world has profoundly affected the peasantry. Accordingly, Turkey has experienced a transformation process in which peasant practices have eroded over time. While the ecological problems and the issues in food, which show an increase with industrialized agriculture, become more critical day by day, the issues of the peasantry and production generate current discussion. On the other hand, Samsun stands out as an important example in terms of its features that contribute to this disputation. This study deals with the peasants of Samsun where a large village population

\begin{abstract}
* Bu makale Ondokuz Mayıs Üniversitesi Kamu Yönetimi Anabilim Dalında 2020 tarihinde kabul edilen "Küresel Kapitalizmle Bütünleşme Sürecinde Türkiye'de Köy Politikası: Samsun Araştırması" adlı doktora tezinden üretilmiştir.

${ }^{1}$ Dr. Samsun, Türkiye
\end{abstract}

ORCID: E.T.B. 0000-0002-4885-6786

Sorumlu yazar/Corresponding author: Ezgi TURMUŞ BINICI,

Atakum, Samsun

E-posta/E-mail: ezgiturmus@hotmail.com

\section{Başvuru/Submitted: 28.04.2021}

Revizyon Talebi/Revision Requested: 01.06.2021

Son Revizyon/Last Revision Received: 11.06.2021

Kabul/Accepted: 11.06 .2021

Atıf/Citation: Turmus Binici, E. (2021). Kapitalist gelişim içinde Samsun köylüsü: Bir alan araştırmasının gösterdikleri. İstanbul Iktisat Dergisi - Istanbul Journal of Economics, 71(1), 317-340. https://doi.org/10.26650/ISTJECON2021-929145 
and high agricultural potential exist. It evaluates the effects of the increasing dependence of the peasantry on the market in the context of capitalist transformation from agriculture to industrialization, based on the field research conducted in the villages. In the interviews with the peasants, problematic subjects such as the issues of property, agricultural support, production, borrowing, change in household labor, the state-peasant relationship are revealed, and the current situation and perceptions of the peasants are evaluated. The first inference indicates the weakening agricultural production in Samsun. The dramatic decrease in the peasant population and migration also shows the change in the dynamics of agricultural production over time. This study aims to discuss the impact and inclusiveness of the policies implemented within the framework of all these problematic issues.

Keywords: Peasantry, Agricultural problem, Global capitalism

JEL Classification: Q10, Q18, P18

\section{EXTENDED ABSTRACT}

Contemporary agricultural problems constitute a crucial global issue due to the monopolization of natural resources in the world. Therefore, policies for villages are also related to ecological problems. When the government pursues the policy of reducing traditional agricultural production and supports corporate agricultural production, a challenging question about food sovereignty arises. Hence, policies for villages in Turkey should be introduced deliberately.

In Turkey, neoliberal policies on agricultural production have been implemented since the 1980s, leaving agricultural production to the free market mechanism and causing peasant production to become more dependent on the capitalist system. Moreover, the financialization of the food regime under the supervision of the International Monetary Fund (IMF) and World Bank (WB) resulted in corporate dominance on agriculture. The renewed international agricultural division and the neoliberal policies have reinforced this dominance.

The case of Samsun reflects the specific features of how the peasantry and peasant production have changed during the neoliberal period. The city is located between two productive plains, half of the population living in rural. Therefore, it is commonly named "the agricultural city" due to these characteristics. Samsun has two separate climatic zones so that four districts have been selected for the field study by considering this situation. The field 
research has been conducted with semi-structured interviews with peasants determined randomly from each district.

In the field study, an interview with 33 peasants about the social and economic conditions of villagers has been carried out. Questions regarding the agricultural production, the livelihood conditions of the villagers, and the change in the conditions have been elaborated. Content analysis has used to examine the results of the interviews. The statement of the peasants reveals the condition of the villagers in terms of their property, production inputs, agricultural supports, agricultural organizations, relations with the market, and creditors. The interviews help us understand the current situation of the peasants, their socio-economic status, and evaluation of the changing conditions from the past to the present.

The field study based on 8 different villages indicates that the problems regarding the support system continue, the changes in the economic conditions are predominant in product preferences, decisions are made individually from the procurement of production inputs to the process of products reaching the market. In addition, it is observed that women fade into the background socioeconomically in villages. The villagers earn their lives by managing debt and conducting animal husbandry, while the number of peasants has gradually decreased. Returning to the village is a rare phenomenon. The study identifies the erosion of the peasant practices as a result of macroeconomic policies cutting agricultural support and hence points out the need for agricultural production planning in Samsun.

Widespread informality in agriculture, rural poverty, migration, and the fact that most of the production is sustained in a subsistence and semi-subsistence form show that policy for villages is necessary and the existing policies should be revised. The villages of Samsun where administrative and problem-solving mechanisms are weakening are left to shrink vis-a-vis the spatial expansion of urban areas in the coast, and the vacant land as agricultural areas that increases towards the interior are abandoned. The inclination of dispossession seems to 
be limited due to the diversity of credit opportunities, the existence of vacant land, and the decline in the demand for land with the intention of cultivation among villagers. The high number of elderly and very low young population in villages, and low propensity to return to the village suggest that the peasantry in Samsun is apt to be left in due course. 


\section{Giriş}

Türkiye'de neoliberal politikalar yoluyla artan sermaye nüfuzu, köylülüğün sermayeye rağmen koruduğu özerk alanı dönüştürmekte ve kapitalist sisteme tabiyetini arttırmaktadır. Hane emeği kapitalist sistem için işler hale geldiği ölçüde, köylülük de kendi içinde farklılaşmakta ve dönüşmektedir. Diğer yandan nüfus artışı, 2000'li yıllarda artık gıda gereksinimini sağlama sorununu ortaya çıkarmıştır. Tarımsal üretim açığı bu dönemde ithalatla kapatılmış ve hatta sadece belli bir açığın kapatılması değil, ülke içindeki tarımsal ürün fiyatlarının ayarlanması politikasının bir gereği olarak ithalat araçsallaştıılmıştır. Girdi fiyatlarının yükselmesi, kırsal yoksulluğun artması, toprağın işlenmekten vazgeçilmesi, kırsal nüfus kaybı sürerken, ithalat ile yerli üretici üzerinde daha büyük bir baskı oluşmuştur. Kırsal alanın neredeyse tek ekonomik kaynağı olan tarımda uygulanan politikalar, sadece 1999-2002 döneminde 450 bin hektar alanın işlenmekten vazgeçilmesine ve (yüzde 9,3 kırsal yoksulluk oranıyla) toprak işleme yeterliliğinin düşmesine sebep olmuş, köylü ise bu şartlar altında sürekli olarak göçe zorlanmıştır (Günaydın, 2010, s. 299-300)

Dünya Kalkınma Raporu 2008 yılında kırsal yoksulluğun ortadan kalkması için üç öneride bulunmuştur: ilki, çiftçilerin küresel tarım ticaretine eklemlenmesi. İkincisi, küresel piyasalara eklemlenme gücü olmayan çiftçilerin kırsalda tarım dışı olanaklara yönelmesi ve işçileşmesi. Üçüncüsü, çiftçilerin kentlere göç etmesidir (Yılmaz ve Kaya, 2017, s. 602). Raporun bakışıla paralel olarak, Türkiye'de de tarımla geçinen kesime küresel piyasalarla bütünleşmek, işçileşmek ya da göçmek yolu dışında yoksulluktan kurtulma imkânı tanınmadığını uygulanan politikalar açıkça göstermektedir.

Finansallaşmış ve şirketleşmiş gıda rejimi içerisinde, Uluslararası Para Fonu (IMF) ve Dünya Bankası (DB) gözetiminde Türkiye, yeni uluslararası tarımsal işbölümüne dâhil olarak tarım üzerindeki şirket egemenliği ve bu egemenliğin önünü açan neoliberal yeniden yapılanma politikalarını uygulamaktadır. Bu yolla, enerji kaynağı olarak tarımsal üretim, sözleşmeli üreticilik, GDO endüstrisi, toprak gaspları giderek yaygınlaşmaktadır. Girdi piyasalarında tohum, gübre ve enerji 
kullanımında yüksek bağımlılığın yanında, çıktı piyasalarında da market zincirleri, tüccarlar ve gıda firmalarına bağımlılık giderek güçlenmektedir. Bunların yanında daha önce de bahsedilen çeşitli yasal düzenlemeler içerdikleri yenilikler bakımından köylü ve köylülerin üretimi açısından dönüştürücü sonuçlar ortaya çıkarmaktadır. Küresel kapitalizmle bütünleşme içerisinde devlet politikalarının tarım sektörünü kontrol edebilme kapasitesinin kalmadığı ve köylüyü de piyasaya karşı korumanın neoliberal anlayış çerçevesinde kalındığı ölçüde mümkün olamadığı görülmektedir (Keyder ve Yenal, 2014, s. 39).

Oysa endüstriyel tarımla birlikte artan ekolojik problemler ve gıda sorunu gün geçtikçe daha görünür hale gelmektedir. Avrupa'da girişimci tarım gerilemektedir ve köylülüğün yeniden açık bir biçimde tartışmalara konu edildiği görülmektedir (Ploeg, 2019, s. 46). Girişimci tarzı üretim yani piyasa odaklı tarımsal üretim ile köylü tarzı üretim yani geçim odaklı sürdürülebilir üretim tartışması yeniden alevlenirken, dünyanın pek çok bölgesinde köylülük hâlâ özgün üretim tarzı ile belli yerlerde varlığını sürdürmektedir ve yeniden köylüleşme süreçleriyle de yeni, küresel bağlar oluşmaktadır. Bu gelişmelerin Türkiye'de özellikle politika düzeyinde belli bir karşıllığı olduğunu söylemek güçtür. Bu çalışma tam da bu sebeple "tarım kenti" vurgusu taşıyan ve ülkenin en çok köyüne sahip beşinci ili Samsun özelinde yapılmış bir alan araştırmasını değerlendirerek var olan politikaların etkisini, köylünün sosyoekonomik koşulları nezdinde değerlendirmeyi amaçlamaktadır.

Çalışmanın temel olgusu olan "köylü", literatürde farklı özellikleriyle tanımlanmıştır. Tarihsel, toplumsal, kültürel bir kategori olan köylülük, Kautsky'nin ifadesiyle arkaik toplumların temelidir (Kautsky, 1988, s. 15). Chayanov'un tespitiyle kendi emeğini sömürerek hayatta kalan, dışarıdaki toplumsal ilişkilerden bağımsız bir olgudur (Özuğurlu, 2013, s. 62). Wolf'un tanımıyla artıkları ya da artıürünü hâkim gruba aktarılan kırsal rençperlerdir ve bu onları ilkellerden ayırmaktadır (Wolf, 2000, s. 18). Bernstein (2014, s. 12) ise çiftçi ve köylü ayrımına dikkat çekerek, her köylünün tam anlamıyla çiftçi olmadığını, çoğunlukla köylülerin geçinmek için yeterli iş ya da gelir sağlamakta yetersiz oldukları için marjinal çiftçilik yaptıklarını belirtmektedir. 
Kapitalist gelişim içerisinde köylünün dışarıdaki toplumsal ilişkilerden bağımsız olmadığını, tam tersine bu ilişkiler içerisinde belirlendiğini görmekteyiz. Köylülük kullandığı girdilerden, artan giderlerine koşut ürününü satmak zorunda olduğu pazara, pek çok aşamada piyasaya bağımlılık içerisinde farklılaşmaktadır. Kimi zaman küçük meta üreticisine dönüşen, çoğu zaman işçileşen, kimi zaman ise yarı işçi yarı geçimlik üretici konumunda olan köylülük, sistem içerisinde varlığını farklılaşarak idame ettirmeye çalışmaktadır.

Köylülüğün farklılaşması günümüze gelinen süreçte mülksüzleşme, toprak ya da emek gücünün kiralanması, girdi ve çıktı kullanımı ve ürün yapısında değişikliklerle daha köklü bir farklılaşmayı beraberinde getirmiştir (Ecevit, 1999, s. 42). Kautsky'nin belirttiği gibi "kırsal nüfusun büyük çoğunluğu, pazarda artık yiyecek maddeleri satıcısı olarak değil, emek-gücü satıcısı ve yiyecek maddeleri alıcısı olarak yer almaktadır" (Bananji'den aktaran Ecevit, 1999, s. 44). Küçük meta üreticisi köylü ise fiyat kontrollerini, pazar düzenlemelerini ve ürüne yönelik bilgiyi belirleyenler tarafından yönlendirilmektedir. Bu bağımlılı sürecinde küçük meta üretimi gerçekleştiren köylünün, tüm üretim sürecinin metalaşmasına karşın, meta dışı kalabilen hane emeği var olduğu ölçüde varlığını sürdürmesi beklenmektedir (Ecevit, 1999, s. 66). Bir diğer seçenek, meta dışı kalamayan hane emeği, "kendini farklılaştıran dinamikler karşısında, "küçük üretici köylü" özelliklerinden uzaklaştığı ölçüde, varlığını idame ettirebilmektedir" (Özuğurlu, 2013, s. 77).

Türkiye'de bu farklılaşmanın incelenmesinde Karadeniz Bölgesinin en gelişmiş ili Samsun, büyük köy nüfusu varlığı, sahip olduğu iki verimli ova ve yüksek tarım potansiyeliyle bir alan çalışması için ciddi olanak sağlamaktadır. Samsun'da genel tablo zayıflayan tarımsal üretime işaret ederken, köy nüfusundaki dramatik düşüş ve göç, kentin geçmişten bugüne getirdiği tarımsal üretim özelliklerinin de değişimini göstermektedir. Köylülerin içinde bulundukları durum bu tabloyu ortaya koyan sebepleri de görünür kılmaktadır. Çalışmada mülkiyet problemlerinden, tarımsal desteleme sisteminin sorunlarına, üretim maliyetlerinden, borçlanma sorununa pek çok güncel başlığın Türkiye'nin genel toplumsal sorunlarıyla paralellik arz ettiği, aynı zamanda belli bir eylemselliği gerekli kıldığı sonucuna ulaşılmaktadır. 


\section{Dünden Bugüne Samsun'da Köylü ve Üretimi}

Samsun'da kapitalist ilişkilerin nüfuzu 19. yüzyılın ortalarına doğru başlamaktadır. Köylünün, geçimlik üretimin yanı sıra pazar için üretim yapmaya başlaması da yine bu dönemde gerçekleşmiştir. 1838 antlaşması ile zirai ürünler üzerindeki tekelin kaldırılması, 1846'da Avrupa ülkelerinde tahıl ithalatı kısıtlamalarının kaldırılması, 19. yüzyılda demir iskelelerin inşa edilmesi ve ulaşımın kolaylaşması, tarımda yerel ürünlerin ihracatını sağlamış ve üretimi teşvik etmiştir (İpek, 1997, s. 36-37). Hububat, pirinç, fındık ve tütün dönemin başlıca ihracat ürünleri olmuştur. 1883 yılında Tütün Rejisinin kurulmasıyla, tütün üretimi katlanarak artmış ve Samsun, Anadolu'ya, İstanbul'a ve Avrupa'ya tütün ihraç eden önemli merkezlerden biri haline gelmiştir (Ertürk Keskin ve Yaman, 2013, s. 9495). Tütün üretimi ihraç ürünleri içerisinde ilk sıraya yerleşmiş ve bu durum Samsun çevresinde de üretimin yaygınlaşmasını sağlamıştır.

Pazara yönelik üretim, sermayenin ihtiyaçları doğrultusunda uluslararası bankaların ve sigorta şirketlerinin açılmasını da beraberinde getirmiştir. Bu dönem gerçekleşen deniz ve karayolları ulaşımında, altyapı koşullarında ve haberleşme olanaklarındaki gelişmeler, Samsun'un sosyo-ekonomik yapısında önemli değişimler yaratmıştır. Köylülerin de bu kapitalistleşme sürecinde pazarla bağı giderek artmış ve tüketim alışkanlıklarında değişimler olmuştur (Ertürk Keskin ve Yaman, 2013, s. 164).

Cumhuriyetin ilanından sonra, 1925 yılında Tütün Rejisi devletleştirilmiş ve TEKEL adını almıştır. Bundan sonra uzun yıllar kurum, Samsun'da destekleme alımları ve fiyat garantisi yoluyla köylü üretiminin güvencesi olmuş, istihdam olanağı yaratmıştır. 1980 yılına gelindiğinde Samsun'un 663 köyünde, 60.541 üretici tarafından tütün üretildiği görülmektedir (Ertürk Keskin ve Yaman, 2013, s. 485). Fakat 1980 'lerden sonra benimsenen neoliberal politikalar çerçevesinde özelleştirme süreci başlamış ve bu kapsamda 2001 yılında tütün üretimini tarladanpazara organize eden TEKEL, özelleştirme kapsamına alınmıştır. Bu gelişmelere karşı TEKEL direnişi ortaya çıkmış fakat bu özelleştirmeye mani olamamıştır. 2008 yılında TEKEL tüm varlıkları ile özelleştirilerek British American Tobacco Firmasına 
devredilmiştir. 2006 yılından 2011 yılına kadar Samsun'da TEKEL'e ait arsa ve binalar satılmıştır (Ertürk Keskin ve Yaman, 2013, s. 438). Samsun'da tütün 2007 yılında 291 köyde 8529 üretici tarafından ekilir hale gelmiştir (Erdoğan ve Akar, 2008, s. 137). Tütünden sonra yaygın üretimi gerçekleştirilen şeker pancarında da benzer bir durum söz konusudur. Samsun'un Çarşamba ilçesinde 1989'da kurulan Çarşamba Şeker Fabrikası, 2009'da özelleştirme süreciyle iki kez satılmak istenmiş ve bu satışlar da iptal olunca fabrika atıl durumda kalmıştır. Bu süreçte köylü de şeker pancarı üretimini giderek bırakmıştır. Son yıllarda fabrikanın tekrar açılacağı gündeme gelse de bırakılan pancar üretiminin nasıl tekrar diriltileceği tartışma konusudur. Bir diğer önemli ürün fındıkta ise bir üretim birliği olan FiSKOBIRLiK'in etkisizleşmesi ve İtalyan Ferrero Şirket'inin büyüyen etkisi göze çarpmaktadır. Samsun şirket açısından en çok verim alınan yer olarak tanımlanmaktadır (Habertürk, 15.05.19). Aynı zamanda fındık hasadının kısa zamanda görece az emek gerektirmesi, Çarşamba ve Bafra ovalarının yaygın bir şekilde fındıkla değerlendirilmesine yol açmış ve uygulamaya konan dikim kararları bu gidişata engel olamamıştır. (Altındeğer, t.y., s. 76)

Köyü kalkındırmaya yönelik politikaların etkisizliği ve pek çok alanda ortaya çıkan politikasızlık Samsun'da da yaklaşık 150 yıldır sürdürülen tütün üretiminin serüveninde olduğu gibi, pek çok açıdan benzer sonuçlar üretmiştir. Tarımsal sorunlardan, göçe, köy altyapı yetersizliklerinden, köylülerin sosyoekonomik durumlarına kadar pek çok konuya ilişkin veriler, aşağıda anlatacağımız gibi kamu politikalarının köy ve köylülük olgularını çoğu zaman teğet geçmekte olduğunu ve küresel kapitalist sistem içerisinde rekabet üzerine kurulu makro politikaların, az sayıda köye yönelen parçalı, dağınık uygulamaları etkisizleştirdiğini göstermektedir. Nihayet tüm bunlar giderek artan bir bağımlılık sürecine de işaret etmektedir.

Samsun toplamda 17 ilçeye ve 951 adet köye sahip bir il (Yılmaz ve Zeybek, 2016, s. 5). Sahip olduğu köy sayısıyla Türkiye'de beşinci sırada yer alırken ülke geneliyle de paralel olarak, hizmet ve sanayinin sektörler içindeki payı artmakta ve tarımın payı giderek azalmakta. Türkiye'nin en önemli iki delta ovası olan Bafra ve Çarşamba ovaları arasında yer alan il, ekonomik ve tarımsal açıdan Karadeniz'in en önemli ili konumundadır. TÜiK verilerine göre 1980 yılında yüzde 65,8 olan 
Samsun kır nüfusunun, 2000 yılında yüzde 47,5, 2012 yılında ise yüzde 32,9'a gerilediği görülmektedir (Yılmaz ve Zeybek, 2016, s. 148). Adrese dayalı nüfus kayıt sistemine göre 2008 tarihinde orman köylüleri Samsun nüfusunun yüzde 71 'ini oluşturmaktadır ve bu nüfusta da ekonomik sıkıntılar ve göçler nedeniyle ciddi düşüşler olduğu belirtilmektedir (Samsun Ili Tarım Master Planı, 2011).

Samsun, tarımsal üretim değerinin Türkiye içindeki payının yüzde 2,66'sını karşılayarak 81 il içerisinde dokuzuncu sırada bulunmaktadır. Buna bakılarak Samsun'un ülke tarımsal üretimine katkısının fazla olduğu görülmektedir (Zeybek, 2006, s. 511). Tarımda çalışanların toplam istihdama oranı ise Türkiye ortalamasının çok üzerindedir. Bu veriler üzerinden kır nüfusunun yanında ilçe merkezlerindeki nüfusun da tarımla geçindiği sonucuna varılmaktadır (Zeybek, 2006, s. 508). Fakat ilde kırsal nüfus başına düşen tarımsal kredi miktarının ülke ve bölge ortalamasından düşük oluşu, tarımla uğraşanların kredi bakımından yeterince desteklenmediğini göstermektedir (Zeybek, 2006, s. 514). Tarım sektörünün yüzde 80'e yakını kayıt dışıdır ve en yoksul kesim kırsalda geçici ve mevsimlik işlerde çalışmaktadır (OKA, 2015, 52-66). Çiftçi Kayıt Sisteminin (ÇKS) problemleri nedeniyle sisteme dâhil olmayan ya da olamayan çok sayıda çiftçi bulunmaktadır. Büyük çoğunluğu geçimlik ya da yarı geçimlik tarımla uğraşan Samsun köylüsünün, 2017 yılı verilerine göre 65.444 ÇKS'ye kayıtlı üreticisi bulunmaktadır (Hekimoğlu ve Altındeğer, 2006, s. 5). Bu rakam 1980 yılındaki toplam tütün üretimi yapan çiftçi sayısı ile neredeyse aynıdır.

Samsun'da 2002 yılında işlenen tarım alanı 342.453 hektar iken, bu alan 2012 yılında yüzde 6,59 azalarak 288.095 hektara inmiştir. İşlenen tarım arazisinde 2012-2014 tarih aralığında ise yüzde 17,8'lik bir azalma olmuştur (STSO, 2016, s. 224). Samsun'un önemli tarımsal faaliyetlerinden hayvancilıkta da gelişmeler olumlu seyretmemektedir. Verilere göre hem büyükbaş hem küçükbaş hayvan varlığı giderek azalmaktadır. Büyükbaş hayvan varlığı 2000-2015 yılları arasında genel olarak düşmüş, 2015 yılı rakamları 2000'li yılların başındaki rakamların altına inmiştir. Bu düşüşlere etki eden şeylerin başında, pazar bulma problemleri, yem fiyatlarının yüksekliği, alınan verimin düşüklüğü ve yetersiz mera alanları bulunmaktadır (Altındeğer, t.y., s. 188-122). Mera alanlarının da 2018 yılında 
yürürlüğe giren Mera Kanunu sonrası 900 hektarlık kısmında tahsis amacı değişikliği olmuş ve hayvancılık açısından zaten yetersiz olan bu alanların giderek azalmasına göz yumulmuştur (Samsun Illi Çevre Durum Raporu, 2018, s. 113). Köy nüfuslarındaki değişim ise dikkat çekicidir: 0-250 nüfus aralığında bulunan köylerin sayısı 2002 tarihinde 256 iken, aynı nüfus aralığında bulunan köyler 2014 yılına gelindiğinde 400'e ulaşmıştır (Yılmaz ve Zeybek, 2016, s. 150). Bu durum köy nüfus büyüklükleri dağılımının değiştiğini ve köylerin büyük bir çoğunluğunun nüfusça küçüldüğünü göstermektedir. Köyde yaşayan nüfus sürekli olarak kente ya da diğer illere göç etmektedir. Öyle ki Samsun en çok göç veren ilk on il arasındadır (Sayılı ve Yulafçı, 2015, s. 405) Göçe dair yapılan bir alan araştırması 2001-2005 tarih aralığında köyde yaşayan 41.754 kişinin en başta, yüzde 90 oranla ekonomik sebeplerle göç ettiğini ortaya koymaktadır (Özışık, 2007, s. 35).

Tüm bu veriler kırsal nüfusun giderek çözüldüğünü ve tarımsal faaliyetin tek başına geçim unsuru olma özelliğinin zayıfladığını göstermektedir. Diğer yandan uygulanan piyasalaştırma politikaları kentte tarım topraklarının kullanımında değişiklikler yaratmaktadır. Samsun'da işlenen tarım alanlarının giderek azalmasında şehrin yatay olarak genişlemesiyle kaybedilen tarım topraklarının varlığı önemli bir unsurdur. Kapaklı ve Toybelen gibi merkeze çok yakın köylerin muhtarlarıyla yapılan görüşmede, toprak satışının giderek arttığı belirtilmiş ve kentin giderek daha geniş alanlara yayılması ile aşağı köylerin tümüyle kentleştiği ifade edilmiştir. Toybelen Köyü ise günümüzde 1500 kişilik nüfusuyla, toprakları büyük ölçüde el değiştirmiş ve büyüyen sanayiye teslim olmuş haldedir. Eski köy muhtarının belirttiğine göre 8000 hektar arazisi olan köyde, şu an 1000 dönüm araziye sahip olan yoktur. Geri kalan topraklar el değiştirmiştir. Yatırımlar ve sanayi o bölgeye kaydığı için hem şahıslar, hem firmalar yer almıştır. Bu bölgenin sanayi bölgesi olarak tasarlanması sebebiyle halen kamulaştırmalar devam etmektedir.

Büyükşehir olduğu 1993 yılından bu zamana Samsun kent alanı, giderek nitelikli tarım arazisi varlığını da yutarak büyümektedir. 1987-2014 tarih aralığında vasfını kaybeden tarım arazisi miktarını il genelinde (Atakum, Ilkadım, Canik ve Tekkeköy) yaklaşık 3.148,90 ha olarak tespit eden bir araştırma, toprak işgalleri karşısında kanunların etkili olamadığını vurgulamaktadır (Uzun ve Demir, 2016, s. 415). 
Özellikle kent merkezlerine yakın köyler açısından bu önlenemeyen rant süreci, tarımsal üretimi bir alternatif olmaktan çıkarmaktadır. Mülksüzleşme her bir yasal değişiklikle daha yaygın hale gelmektedir.

Mülksüzleştirmenin başka bir görünümü de tarım alanlarının yatırımlara tahsis edilmesi ve kârlılık alanlarına dönüștürülmesidir. Son dönem gündeme sıklıkla gelen Lojistik Köy, birinci sınıf tarım arazileri üzerine inşa edildiği için davalık olmuş, hem Samsun Ziraat Mühendisleri Odası hem de köylüler yönetime karşı açtıkları davaları kazanmıştır (Akduman, 2019). Buna rağmen bu kurum kanunsuz şekilde de olsa faaliyetini sürdürmektedir. Diğer yandan yine Çarşamba ilçesinde nitelikli tarım arazileri üzerinde faaliyete geçecek olan Biyokütle Santrali için olumlu yönde karar veren belediye, sivil toplum örgütleri ve halkın tepkisini göz ardı ederek yine sermaye yanlısı bir tutum izlemektedir. Tüm bu gelişmeler "tarım kenti" ifadesinin gerçekliğini sorgulatırken, tarıma sektörel bakışın da köylülüğün gözden kaybedilmesiyle sonuçlanacağını düşündürmektedir.

\subsection{Alan Araştırması ve Gösterdikleri}

Buraya kadar Samsun'da köylü ve üretimine ilişkin ortaya konulan genel durumun olumlu seyretmediği görülmektedir. Bu genel görünüm ışı̆̆ında köy alan araşstırmasıyla toprak mülkiyeti, hane emeği ve topraktan pazara üretim özellikleri ile köylülerin politikalara yönelik tutumu ele alınarak köylülerin perspektifinden konu irdelenmeye çalışılmıştır.

\subsubsection{Araştırmanın Yöntemi}

Alan araştırması kapsamındaki görüşmeler 2016 tarihli Ondokuz Mayıs Üniversitesi Sosyal ve Beşeri Bilimler Etik Kurul Kararı alınarak 2017-2018 yılları içerisinde gerçekleştirilmiş ve köylülere 42 başlıktan oluşan, hem demografik ve sosyo-ekonomik içerikli hem de tarımsal üretimle ilgili yarı yapılandırılmış sorular yöneltilmiştir. Maksimum çeşitlilik örneklemesi gereği, ayırt edici kılma ihtimali olduğu düşünülen iklimsel ve coğrafi konum farklılıkları ve farklı ilçelere bağlı oluş gibi nitelikler üzerinden belirlenen örneklem, farklı coğrafi konumlar ve farklı 
ilçelere bağlı köy ve köylüler seçerek oluşturulmuş ve bu seçilim rastgele (tesadüfi) örnekleme yoluyla yapılmıştır. Sahil kesiminden 4 ilçe, iç kesimden 4 ilçeye bağlı toplam 8 ayrı köyde, 33 köylü ile yapılan görüşmelerde, görüşme formu kullanılarak, önceden hazırlanmış olan yarı yapılandırılmış sorular yöneltilmiş ve konuyu derinlemesine irdeleyebilmek için ek sorular sorma özgürlüğünden yararlanılmıştır. Son olarak elde edilen veriler içerik analizine tabi tutularak değerlendirilmiştir. Ayrıca tarımsal üretimin sürdürülmemesine sıkça rastlandığı için, köylülerin seçiminde az da olsa tarımla uğraşıllyor olmasına dikkat edilmiştir. Araştırma yapılan köyler ve bağlı bulundukları ilçeler şöyledir:

Tablo 1: Alan Araştırmasının Gerçekleştirildiği İlçe, Köy ve Köylü Sayıları

\begin{tabular}{|c|c|c|c|c|c|c|c|}
\hline \multicolumn{7}{|c|}{ İç Kesim } & \multicolumn{4}{c|}{ Sahil Kesimi } \\
\hline Vezirköprü & Havza & Kavak & Lâdik & Bafra & Çarşamba & Terme & Atakum \\
\hline Adatepe & Karga & Hacılı & Büyükalan & Çetinkaya & Kurtahmetli & Dibekli & Acısu \\
3 köylü & 3 köylü & 3 köylü & 6 köylü & 6 köylü & 6 köylü & 3 köylü & 3 köylü \\
\hline \multicolumn{7}{|c|}{ Toplam Köy Sayısı: 8 } \\
Toplam Köylü Sayısı: 33 \\
\hline
\end{tabular}

Gidilen köy sayısı ve görüşülen köylü sayısı, ulaşım ve zaman kısıtları altında olabildiğince fazla tutulmaya çalışılmış, temel iki iklimsel bölgeye ayrılan Samsun'un her iki bölgesinden de belli sayıda köy ve köylü örnekleme dâhil edilmiştir. Karşılaşılan ve sohbet edilen bir kısım köylünün yaşlılık durumları ve tarımsal üretimi sürdürmemesi görüşme yapılan kişi sayısına doğal bir sınır oluşturmuştur. Bunun yanında farklı köy ve köylülerden elde edilen verilerin bir süre sonra büyük ölçüde kendini tekrar ettiği gözlemlenmiştir. Bu da görüşmelerin belli bir noktada yeterli olduğu kanısını uyandırmıştır.

Araştırma alanı olan Samsun, sahil bölgesi ve alt bölümü olmak üzere iki farklı iklimsel bölgeye sahiptir. Sahile yakın bölümünde Bafra ve Çarşamba ovalarının da etkisiyle, verimlilik fazladır. lç kesimlere gidildikçe karasal iklim kuşağı başlamaktadır ve bu durum üretilenleri ve üretim sürecini belli açllardan etkilemektedir. Genel olarak son otuz yılın politikalarının köylülük ve köylü üretiminde temelde iklim farklı gözetmeksizin aynı sonuçları ortaya çıkardığı söylenebilir. İklimsel farklılık yalnızca ortaya çıkan benzer sonuçların şiddetinde bir farklılık olarak değerlendirilebilir. Sahil 
bölümünde yaşayan köylüler verimlilik ve sulama olanakları ile farklı alternatiflere sahip olma ya da farklılıklara uymaktaki yüksek toleransı nedeniyle sorunları görece daha kolay aşabilmektedir. Fakat sorunların her iki bölge açısından da göç yoluyla aşılmasının yaygın olduğunu veriler ortaya koymaktadır.

Köylüler çoğu zaman maddi durumlarını ilgilendiren konularda kısa cevaplar vererek, soruları geçiştirmek istemişlerdir. Kimi zaman yanıt alınamayan sorulara, başka bir soru yoluyla cevap almak mümkün olmuştur. Bu bazen soruları anlamakta güçlük yaşamalarından, bazen ise güven probleminden kaynaklanmaktadır. Bunun dışında misafirperver oldukları kadar, sıkılgan, bıkmış, şüpheci ve dışlayıcı oldukları da zaman zaman hissedilmektedir. Bu olumsuz gibi görünen özellikler, toplamda olumsuz olarak değerlendirilmemiştir. Köylü için dışarı ile ilişkiye girdiği her yaşamsal bağlantı, faydasız olarak kodlanmış görünmektedir. Yapılan görüşmelere yönelik tavırları yer yer güçlü dert yanmalar yer yer bunların faydasız, anlamsız olduğuna yönelik bıkkınlık duygusuyla örtüşsmektedir.

\subsubsection{Toprak Mülkiyeti}

Araştırma yürütülen köylerde görüşülen köylülerin kullanımında olan toprak büyüklüğü miktarı 10 ila 200 dönüm arası değişmektedir. Bunların büyük bir çoğunluğu 20-80 dönüm arası toprak kullanmaktadır. Fakat toprak sahipliği açısından durum farklıdır. Görüşülen köylülerin yarıına yakını babadan kalma toprak üzerinde ya veraset intikali yapılmaması ya da toprağın kardeşler arasında bölüşülmemiş olması sebebiyle, kendilerine ait görünmeyen topraklar üzerinde çalışmaktadır. Bu durum aynı köylülerin desteklerden de yararlanamaması anlamına gelmektedir. Desteklemeler arazi bazlıdır ve kendine ait bir tapun olması koşuluyla ya da sözleşme yapılması halinde verilmektedir. Bazı köylülerin belirttiğine göre veraset intikali fazla para ödemeyi gerektirmektedir ve destekten faydalanmak adına bu yükün altına girmek anlamsızdır. Bu eğilimi taşıyan köylülerin üretimleri önemli ölçüde geçimliktir. Aile büyükleri halen yaşayan hanelerde desteklerden faydalanılmaktadır.

Köylülerin yarısından fazlası mazot, gübre, buğday, mısır, fındık, fiğ, arazi, sılaj ve hayvan desteklerinden yararlanmaktadır. Bazı köylüler ise destek almayı 
bırakmıştır. İstisnasız, destek alan ve destek almayı bırakan köylülerin tamamı, desteklerin yetersiz olduğundan yakınmaktadır. Girdi maliyetlerini geçmiş maliyet ve kazanç durumu ile kıyaslayan köylü, şu an içinde bulunduğu durumu çok kötü olarak değerlendirmektedir. Destek almayı bırakan 3 köylü ise destek alma sürecinin yoğun bürokrasisini eleştirmekte ve alınan destekle destek almak için ödenen para arasında çok fark olmadığını ve bununla uğraşmaya değmediğini dile getirmektedir. "Desteklemelerin aslı astarı yok", "destek almak için ya bir şeyleri eksik ya bir şeyleri fazla göstermek gerekiyor", "verdiği ne ki, almıyorum kaç senedir", "destek için başvurdum bir sefer, bir sene yenileme yapmadık diye kestiler, uğraştığına değmiyor. 130 lira alacağım, 140 lira masraf ediyorum, tapuya git, kooperatife git..." gibi ifadeler desteklere yönelik olumsuz ifadelerden bazılarıdır.

Görüşme yapılan köylülerin önemli bir bölümü kamu bankalarından ya da özel bankalardan, üretimleri ya da genel ihtiyaçları için kredi kullanmaktadır. Özel bankaların yüksek faizli borçlandırmalarının zarara uğrattığı düşünüldüğü için genel olarak kamu bankası olan Ziraat Bankası tercih edilmektedir. Hiçbir kredi kullanmadığını söyleyen az sayıda köylüden çoğu ödeyemeyeceğini bildiği için bu yükün altına girmediğini ifade etmiştir. Gerek görüşülen ve kredi kullanan köylülerin, gerek ziraat odası çalışanlarının, gerekse muhtarların beyanları, köylünün borcu borçla kapattığı yönündedir. Bir bankadan aldığını diğer banka kredisiyle kapatarak, borcun sürdürülebilirliğini sağlayan köylüler için durum pekiyi görünmemektedir. Görüşme yapılan ilçelerden birinin Ziraat Odası çalışanının bu konu hakkındaki ifadesi şöyledir: ${ }^{1}$

Şimdi köylü borç döngüsü içinde. Edirne ve Trakya'da banka ürüne el koymuş diye duyduk. Bizde de fazla uzun sürmez. Şekerbank, Deniz Bank, Türkiye Ekonomi Bankası. Borcu takla attırıyor köylü. Tıkanıncaya kadar ki çoğu tıkandı. Eylül ayında bankayı görürsün, kuyruk. Aldıkları borcun faizini yatırmak için.

1 Köylülerden yapılan alıntılar alan araştırmasında gerçekleştirilen görüşmelere dayanmaktadır. 
Üretimin maliyeti giderek artmaktadır ve köylünün üretimin getirisini eski dönemlerle kıyas etmesi istendiğinde, yaptıkları hesap ve ifadeleri benzerdir. Sürekli olarak karşılığını alamadıkları bir üretimden yakınmaktadırlar.

Genel olarak bakıldığında, toprağı kendine ait olmayan ya da görünmeyen bir köylünün destek alması mümkün değildir. Destek alınmadığı takdirde, hele bir de işlediği toprağın kiracısıysa üretim yapmak olanaksızlaşmaktadır. İhtiyaçların metalaşması arttığı ve emeğin kendini sömürme olanakları azaldığı ölçüde, köylünün ayakta kalma direnci de azalmaktadır. Şu sözler bu durumu açıklayıcı görünmektedir:

Eskiden mazot denen şeyi tanımıyordu köylü, gübre yoktu, beden gücü vardı, değirmen vardı, şimdi parası olmayanın buğday ekme şansı yok. Mazota, traktöre ve bunun gibi şeylere ihtiyacı var. Bu civardakiler, mutlaka günü kurtarmak için aşağı [kente] iniyor. Bir yerde çalışmak istiyor. Eskiden köylü para görmüyordu ama azığı da eksik olmuyordu. Ambar hep doluydu. Üç gün aşağı gitmese şimdi, dördüncü gün aç kalıyor.

Köylülerin çoğunluğu toprak alıp satmamıştır. Hane emeği fazla olan ve refah koşulları görece iyi olan birkaç köylü dışında üretim yoluyla toprak alan yoktur. Toprağı kiralama yoluyla ve ortakçlık usulüyle tarım yapan sayısı 4'tür. Fakat bu özellikler daha çok Kavak, Vezirköprü gibi iç kesimlerde yer alan ve önemli ölçüde nüfus kaybeden köylerde görülmektedir. Köylüler, göçlerle birlikte boşalan ve değerlendirilmeyen araziler olduğunu ve kira veya ortakçllk yoluyla bunların değerlendirildiğini ifade etmiştir.

Borcu nedeniyle hayvan veya toprak satan toplamda dokuz köylüdür. Köylüler kimi zaman emekli olabilmek için, kimi zaman ise eve yönelik ihtiyaçları için hayvan satmaktadırlar. Toprak ve hayvan gibi üretimin temel unsurlarının, belli bir güvence ve refahın sağlanması adına gözden çıkarılması gerektiği gözlemlenmektedir.

\subsubsection{Hane Emeği ve Değişen Üretim}

Görüşme yapılan köylülerin yaş ortalaması 50'dir. Eğitim durumlarının ise çoğunlukla ilkokul mezunu olduğu görülmüştür. Ortalama hane sayısı 5'dir. Hane 
sayıları 2 ile 10 arası değişmektedir. Yıllar içinde artan göç ve genç nüfusun köylerde kalmayışı, köylünün şu an ki yaşamında nüfus faktörünün önemli bir belirleyiciliği olduğunu göstermektedir. Köyden çıkanların köyle bağı kopmuş değildir. Köyde kalanların, dışardakilere yardımı, köy dışındakilerin köydekilere yardımı da çoğu zaman sürmektedir. Köylülerin çoğunluğunun emekli maaş geliri bulunmaktadır ve bunun yanı sıra tarımla uğraşmaktadır. Özellikle kadınların eşlerinden dolayı sigortadan yararlandıkları ve yine eşlerinin emekli maaşı ile geçim sağladıkları görülmektedir. Görüşme yapılan çoğu erkek köylünün, hane kaç kişiden oluşuyor diye sorulduğunda, hane içindeki kadınları sayıya dâhil etmeden cevap vermeleri kadınların hem ekonomik hem de sosyo-kültürel bağlamda ikinci planda tutulduklarını göstermektedir. Aynı şekilde köyde yaşamaya devam eden gençler de yaptıkları tarıma ek olarak, anne ya da baba maaşı ile geçimini sürdürmektedir.

Yapılan tüm görüşmelerde, köylüler gerek ürün değiştirme sebeplerini açıklarken gerek geçim zorluklarından ve geçmiş köy hayatından bahsederken azalan nüfusun olumsuz etkisinden bahsetmektedir. Köylüler, tarım politikalarının yanı sıra azalan hane emeğinin bir sonucu olarak yılın belli bir dönemi çalışmayı gerektiren ve daha az emek isteyen ürünlere yönelmektedirler. Eskiden tütün, buğday üretimini yoğun olarak gerçekleştiren köyler, aynı yerlerini bugün kavak yetiştirerek ya da fındıkla değerlendirmektedir. Çarşamba gibi verimli arazilere sahip olan bir bölgede dahi, tarlaların yerini bahsedilen ürünler ve daha önce denenmemiş fakat desteklenen ve parasal getirisi ihtimali yüksek olan kivi gibi ürünler almaktadır. Çoğu köylünün eskiden üretirdik dediği pancar, bugün çok az köylü tarafından üretimi sürdürülen bir üründür. "Tarımsal üretimin toplumsal ihtiyaçlar açısından öncelikli (ama kâr marjı düşük) ürünlerden uzaklaşıp parasal kazancı yüksek ürünlere yönelmesinde temel faktör devletin aradan çekilmesiyle oluşan bu bağımlılık ilişkileridir" (Önal, 2019, s. 67) ifadesi serbest piyasaya bağımlılık koşulları altında köylülerin neden bu gibi davranışlara yöneldiğini en yalın haliyle açıklamaktadır.

Eskiden sebze de yetiştiren köylülerin büyük bölümü bu üretimi bırakmalarını parasal getirinin az olmasıyla ilişkilendirmektedir. Fakat "bugün istesek de artık kalabalık değiliz" diyerek, çalışan olmayışının istenilen üretimi gerçekleştirmenin 
önünde ikinci büyük engel olarak ortaya çıktığı ifade edilmektedir. Aynı şekilde daha fazla toprağa sahip olma isteklerinin olmadığını dile getiren birçok köylünün gerekçesi, kendilerinin çalışmaya güçlerinin yetmediği ve çalışabilecek bir nüfusun olmayışıdır.

Görüşme yapılan tüm köylerde önemli ölçüde nüfus kaybı vardır. Özellikle iç kesimlere gidildikçe, yaz-kış köyde yaşayan hane sayısı ciddi oranlarda düşmektedir. Yine iç kesimlerdeki köylerde genç nüfus parmakla sayılmaktadır. Örneğin Kavak'ın Hacılı köyünde otuz yaş altı yalnızca iki kişi yaşadığı belirtilmiştir. Büyükalan köyünde ise yaşayan kişi sayısı ellidir ve bunun yalnızca sekiz kişisi otuz yaş altıdır. Köye dönen var mı sorusunun cevabı çoğu zaman olumsuzdur. Yalnızca birkaç köylü, emekli olup köye dönen olduğunu belirtmiştir ki bu durum sahil bölgesinde daha sık karşımıza çıkmaktadır. Emekli olup dönenler ise üretim amaçı ı dönmemektedir. Bir köylünün tabiriyle köy "on sene sonra bayramlık köy" olacaktır. Arazide çalışan insanlar yaşlıdır ve gençler kentte asgari ücretle çalışmayı köyde yaşamaya yeğlemektedirler.

Her köyde hayvancılık yapan sayısı giderek azalmıştır. Görüşmelerde büyük ölçüde geçimi için hayvan besleyen köylü sayısının geçmişten bugüne çok azaldığı köylülerce dile getirilmiştir. Her köyde belli başlı kişilerin (bunların genellikle muhtar olduğu göze çarpmaktadır), çok sayıda hayvan edinerek ticaret amaçlı hayvancılık yaptığı görülmektedir.

Köylülerin yarısından fazlası üretim sürecinde işçi tutmamaktadır, hane içi emek hala yaygın olarak kullanılmaktadır. Yevmiyeli işçi çalıştıranların önemli bir bölümü sahil bölgesinde fındık üretimi için buna ihtiyaç duymaktadır. İç kesimlerde ise az sayıda köylü pancar ve tütün için işçi çalıştırabilmektedir. Eskiden çalıştırıp bugün üretimi küçüldügü için iş̧̧i çalıştırmayı bırakan köylülere de rastlanmaktadır.

Köyün yaşadığı nüfus kaybı, tarımsal üretime azalan desteğin olumsuz etkisini gölgeler niteliktedir. Köylünün dikkat ettiği husus üretimin artan maliyeti, yüksek girdi fiyatları ve girdi temininde sebeplerini çoğu zaman idrak edemedikleri artan dışa bağımlılıktır. 


\subsubsection{3. Üretim Sürecinde Köylü: Girdi Temininden Pazara}

Köylüler üretimin ilk basamağından pazarlanmasına kadar birçok aşamada farklı içsel ve dışsal etkenlere bağımlıdır. Öncelikle tohum, gübre, ilaç, üretim araçları gibi birçok girdinin temin edilebilmesi için belli bir maliyete katlanılmak zorundadır. Görüşme yapılan köylülerin tamamı, tohumu her yıl yeniden satın alarak üretim gerçekleştirmektedir. Çoğu 15 yıl önce yerli tohumu bıraktıklarını dile getirmektedir ve satın alınan tohumların veriminin fazla olması en sık söylenen gerekçedir.

Hibrit tohumların verimliliği arttıran özellikleri bir müddet sonra toprağın yorulmasına sebep olurken, kullanılan kimyasal gübreler de toprağın yapısını değiştirmektedir. Bu kullanıma alışan toprak açısından, her seferinde daha çok gübreleme ve sulama ihtiyacı ortaya çıkmaktadır. Bu kısır döngü içerisinde "topraklar gübreye alışmıs, atmadan olmuyor", "eskiden ektiğimiz yıllarca giderdi, şimdi her sene tohum alıyoruz, ikinci kez ekme şansın yok", "ilaçlar toprağı küstürdü, bu sene ürün alamadık", "gübreyi ilacı fazla atman gerek başka türlü vermiyor" gibi ifadelerle sıkça karşılaşılmaktadır.

Artan girdi maliyetlerinin, uygulamaya konulan tarım politikalarının ve azalan nüfusun etkisinde üretime konu olan ürünler değişmektedir. Görüşmelere dayanılarak üretimi bırakılan ürün ve alanlar şu şekilde tespit edilmiştir: Tütün, buğday, mısır, fasulye, sebzecilik, sılaj mısırcılığı, pancar, kendir ve hayvancılık. Bunların içinden fazla sayıda kişi tarafından üretimi bırakılanlar ise tütün, pancar ve buğdaydır. Ülke genelinde uygulanan pancar, tütün ve buğday konusunda üretici köylünün çıkarlarını gözetmeyen üretim ve fiyat politikalarının, beklenen haliyle Samsun'un üretici köylüsü açısında da benzer sonuçları ortaya koyduğu görülmektedir.

Köylü ürününü, fındıkta genellikle mağazalara, diğer ürünlerde fabrikaya, tüccara, esnafa ya da nadiren doğrudan pazara vermektedir. Üretim sürecinin bütününde köylünün ürettiği değer, devlet kurumları, bankalar ve alıcı 
konumundaki fabrika ya da tüccar arasında bölüşülmektedir. Köylü "1 milyon destek alacaksan, 400 TL veriyorsun, sekiz ay sonra 600 TL alıyorsun. Yüzde 4 yatan paradan banka kesiyor. Köylü hariç herkes kazanıyor" derken, bu süreci belli bir yönüyle ifade etmeye çalışmaktadır.

Köylülerin kooperatiflerle bağı yok denecek kadar azdır. Çoğunun kooperatifle bir ilişkisi yoktur, ilişki kurmak isteğinde olan birkaç köylü için ise sayıca azalan ve taşınan kooperatiflere ulaşmanın eskiye oranla çok zor olduğuna değinilmiştir. Eskiden yoğun bir şekilde kooperatiflerle ilişkili olan birkaç köylünün ise kooperatiflere yönelik düşüncesi olumsuzdur. "Tütün kooperatifi vardı zamanında ondan faydalandık. Devlete, hortumculara iyi çalışık... Kooperatife çok para ödedik, herkes birbirine kefildi" diyen bir köylü ve "Kooperatif kuruluyor, içine bir hırsız giriyor. Yürümüyor" diyen bir başka köylü, kooperatiflerin çok önce anlamını yitirmesine sebep olan durumlara dair fikir vermektedir. Bu durum, Samsun özelinde kooperatif ve üretici birlikleri üyeleri ve hiçbir üyeliği bulunmayan çiftçilerle gerçekleştirilen anket çalışmasının vurguladığı olumsuz sonuçlarla da paralellik göstermektedir (Aydoğan ve Yulafçı, 2013, s. 28).

Görüşme yapılan köylülerin çoğunun traktörü vardır. Diğer üretim araçlarına da çoğu sahiptir ya da kolay ulaşmaktadır. Fakat dikkat çeken nokta, bir köyde bulunan traktör sayısı ile yirmi köyün işinin yapılabilir oluşudur. Köylüler, geçmişteki tarımsal kazançlarını bu üretim araçlarına yatırmıştır ve bugün de iyi kazanç getiren bir senenin getirisi kullanılarak traktör almayı seçmekte ve borç ödemektedir. Üretim araçlarının kolektif kullanımının mümkün olması halinde hem köylünün kazancını farklı kanallara yönlendirebilmesi hem de büyük bir israfın önüne geçilmesi mümkün olabilir.

Kısaca köylünün birlikte hareket etmek, örgütlenmek konusunda çok zayıf olduğu, herkesin kendi refah koşullarını rekabet halinde sağlamaya çalıştığı, bu süreçte de dışsal bağımlılıklar ve maliyetler konusunda şikâyet ettiği, bireysel olarak mücadele ettikleri konularda bütünüyle pasif olduğu ve bir araya gelmek konusunda istekleri olmadığı görülmektedir. 


\subsubsection{Köye Yönelik Politikalara Bakış}

Köylülerin çoğunluğunun, üretimlerine ve yaşamlarına etki eden politikaları verili bir durum olarak kabul etme eğiliminde oldukları görülmektedir. Üretim ve geçim sıkıntılarından bahsederken, geçmişten bugüne durumlarının kötüleştiği değerlendirmesini yapmaktadırlar, fakat bu durumu ortaya çıkaran sebepler konusunda yeterince net değillerdir. Sıkıntılar birçok sebebe bağlı ve süreçlidir. Bu durum uygulanan politikalara yönelik pasif bir tutumu beraberinde getirmektedir.

Görüşme yapılan köylülerin hemen hepsi, verilen emeğin karşılığının alınamayışından, girdilerin pahalılığından yakınmaktadır. Fakat bunlardan ancak bazıları bulundukları durumu doğrudan köylüye ve köylünün üretimine etki eden politikaların güncel etkisiyle ilişkilendirmektedir. Görece daha iyi refah koşullarına sahip olan köylülerde, üretim ve yaşam kalitesi ile kamu politikaları arasındaki sebep sonuç ilişkisinin daha net kurulduğu gözlemlenmektedir. "Köylülük bitiyor", "çiftçilik kalktı, gitti, bitti", "köyü bitirdiler, 1998'den bu yana nüfus kalmadı", "geriye gidiyoruz devamlı", "evlerin içi boş, virane artık" gibi pek çok söylemde uygulanan politikalarla ilişki kurulmaktadır.

Pancara konulan kota ve nişasta bazlı şekere yönelik desteklemelerle pancar üretiminin bıraktırılması, devletin tütün alımını tümüyle kaldırması ve tütün ekimini bırakan büyük bir nüfusun ortaya çıkışı, birçok köylünün dile getirdiği ve şikâyet ettiği politikalardan yalnızca birkaçı olarak karşımıza çıkmaktadır.

\section{Sonuç}

Samsun'da tarımda kayıt dışlığın yoğunluğu, kırsal yoksulluk, göç ve üretimin büyük bir bölümünün geçimlik ve yarı geçimlik karakterde sürdürülüyor oluşu, belli bir köy politikasının gerekli olduğunu ve var olan politikaların sürece olumlu etki etmediğini göstermektedir. İdari açıdan kendi ihtiyaç ve sorun giderme mekanizmalarını kaybetmiş ve giderek küçüldüğü görülen Samsun köyleri, mekânsal açıdan sahil kesiminde kentleşerek, iç kesimde ise giderek boşalan arazi varlığı ve terkedilen tarımsal üretim ile karakterize olmaktadır. Mülksüzleşme 
eğilimi ise borçlanma olanaklarının çeşitliliği, nüfusun azalmasına bağlı boşalan arazi varlığı ve çalışacak nüfus yokluğu sebebiyle ortaya çıkan toprağa yönelik talepsizlik ile sınırlandırılmış görünmektedir. Görüşme yapılan köylülerin yaş ortalamasının yüksekliği, pek çok köyde genç nüfusun çok az olması ve köye geri dönüşün nadir gerçekleşmesi Samsun'da köylülüğün belli bir vadede tasfiye olacağını düşündürmektedir.

Alan çalışmasının sonuçları bize, çoğu zaman köylülerin üretimin olası külfetlerine katlanmaktansa tarımsal üretime devam etmemeyi daha anlamlı bulduklarını ve mülkiyet faktörünün üretim açısından kritik bir rol oynadığını göstermektedir. Destekleme sistemini etkisizleştiren bürokrasi, maliyet ve bağımlılık koşullarının bulunduğu, kadınların sosyal ve ekonomik koşullarının zayıf olduğu, üretimin herhangi bir planlamasının olmadığı ve kısa vadede gelir getirecek ürünlere yönelerek köylünün geçmişten bugüne ürettiği ürünleri bırakmayı tercih ettiği araştırmanın diğer gösterdikleri arasındadır. Hayvancılı̆ın giderek azalmakta, girdiler bakımından bağımlılık artmakta ve borçlanma kanalları yoğun bir şekilde kullanılmaktadır. İmecenin büyük ölçüde ortadan kalktığı, kent ve kır arasındaki bağların hâlâ sürdürüldüğü, köye geri dönme eğiliminin çok nadiren görüldüğü ve köylülerin kolektif hareket etme konusunda motivasyonlarının olmadığı anlaşılmaktadır.

Kırsal halkın refahından çok, tarımsal kapitalizmi amaçlayan politikaların hem kullandığı politika araçları açısından hem 1980'lerden sonra liberal bir yol izleyen politikaların "başarı" kriterleri açısından, Samsun'un görece yüksek kırsal nüfusunun ve tarımsal üretim yoğunluğunun gerçekte bir değer olarak kabul edilmediği anlaşılmaktadır. Gülçubuk'un (2013, s.17) belirttiği gibi, "Tarımın canlı yaşamındaki önemini sadece ekonomik paradigma ile ele almak toplumsal gerçekliği ve bağımlı yaşam ilişkilerini göz ardı etmektir. Böyle bir bakış açısı beraberinde sadece sektörel bakışı getirir." Görünen o ki ülke genelinde olduğu gibi Samsun'da da tarıma "sektörel bakış" egemendir.

Alan çalışmasının sonuçları çerçevesinde, il genelinde farklı kurumlarca yürütülen faaliyetlerin köy alanına yansımalarının çok sınırlı olduğu görülmüştür. Destekleme sisteminin sorunları sürmekte, ürün tercihlerinde değişen ekonomik koşullar 
belirleyici olmakta, üretim girdilerinin temininden ürünlerin pazara ulaşma sürecine kadar kararlar bireysel olarak verilmekte, özellikle iç kesimlerde sulama olanaksızlıkları sıklıkla dile getirilmektedir. Araştırmanın tüm verileri değerlendirildiğinde ortaya çıkan köylü resmine bakarak, köyün ve köylü üretiminin neoliberal politikalardan kaynaklı problemlerini bertaraf edebilecek ve sürdürülebilirliğini sağlayacak politikalara ihtiyaç olduğu anlaşılmaktadır. Mülkiyet kaynaklı problemlerin giderilmesi, piyasaya bağımlılığının azaltılması ve kolektif hareket edebilme olanaklarının arttıııması ise temel sorun alanları olarak karşımıza çıkmaktadır.

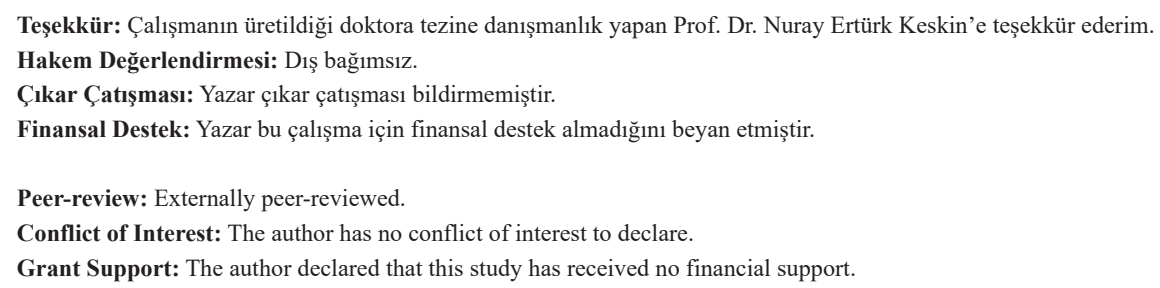

\section{Kaynaklar/References}

Akduman, I. (2019, 7 Mart). 300 milyon lira çöp mü olacak! Tarım arazisine yapılan lojistik köye iptal kararı. Sözcü, https://www.sozcu.com.tr/2019/gundem/50-milyon-euro-cop-mu-olacak-tarimarazisine-yapilan-lojistik-koye-iptal-karari-3818107/.

Altındeğer, M. (t.y.). Samsun Tarımı́na Analitik Yaklaşım (2000-2015). Samsun Gıda Tarım ve Hayvancilık ill Müdürlüğü, Samsun.

Aydoğan, M. ve Yulafçı, A. (2013). Samsun Ilindeki Tarımsal Üretici Örgütlerinin Yapısal Sorunlarının Belirlenmesi. T.C. Gıda, Tarım ve Hayvancılık Bakanlığı Tarımsal Araştırmalar ve Politikalar Genel Müdürlüğü Karadeniz Tarımsal Araştırma Enstitüsü Müdürlüğü.

Bernstein, H. (2014). Tarımsal Değişimin Sınıfsal Dinamikleri. Çev. Oya Köymen, Yordam Kitap, İstanbul.

Ecevit, M. C. (1999). Kırsal Türkiye'nin Değişim Dinamikleri Gökçeağaç Köyü Monografisi. T.C. Kültür Bakanlığı Yayınları, Ankara.

Erdoğan M. V. Ve Akar, M. (2008). Yitip Giden 'Tütün' ve Özelleşen 'Tekel'. TMMOB Samsun Kent Sempozyumu, 130-139.

Ertürk Keskin, N. ve Yaman, M. (2013). Türkiye'de Tütün Reji'den TEKEL'e TEKEL'den Bugüne. NotaBene Yayınları, Ankara.

Gülçubuk, B. (2013). Türkiye Tarımının Ekonomi-Politik ve Sosyolojik Nitelikleri Açısından Arazi Toplulaştırmaları. GTHB-Türktarım Dergisi, Sayı:210, Mart-Nisan 2013, 16-21.

Günaydın, G. (2010). Tarım ve Kırsallıkta Dönüşüm Politika Transferi Süreci AB ve Türkiye, Tan Yayınları, Ankara. 
Habertürk (2019, 15 Mayıs). 35 bin fındık üreticisine değerli tarım anlatıldı. https://www.haberturk. com/samsun-haberleri/69091582-35-bin-findik-ureticisine-degerli-tarim-anlatildi.

Hekimoğlu, B. ve Altındeğer. M. (2006). AB Ortak Tarım Politikaları ve DTÖ Kararları-Bunların Ülke ve Bölge Tarımına Etkileri. T.C. Samsun Valiliği Tarım IIl Müdürlügü̈, https://samsun.tarimorman.gov. tr/Belgeler/Yayinlar/Tarimsal_strateji/AB_ortak_tarim_politikalari_ve_DTO_kararlari_bunlarin_ ulke_ve_bolge_tarimina_etkileri.pdf, Samsun.

İpek, N. (1997). Canik Sancağı'nın Nüfusuna Dair Bir Değerlendirme. Ondokuz Mayıs Üniversitesi Eğitim Fakültesi Dergisi, Sayı:10, Samsun.

Kautsky, K. (1988). The Agrarian Question, Zwan Publications, London.

Keyder, Ç. ve Yenal, Z. (2014). Bildiğimiz Tarımın Sonu Küresel Iktidar ve Köylülük, İletişim Yayınları, İstanbul.

Orta Karadeniz Kalkınma Ajansı (OKA). (2015). Samsun Illi Sosyal Analiz Raporu 2015, https://www. oka.org.tr/Documents/SAMSUN_SOSYAL_ANALIZ_RAPORU.pdf, Samsun.

Önal, N. E. (2019). Tarımsal Ürün Fiyat Artışlarının Türkiye Tarımının Yapısal Sorunlarına Dair Gösterdikleri. Beykoz Akademi Dergisi, 62-74.

Özışık, Ş. (2007). Samsun Köylerindeki Göç Hareketleri ve Sebepleri, Ondokuz Mayıs Üniversitesi Yayınları, Samsun.

Özuğurlu, M. (2O13). Küçük Köylülüğe Sermaye Kapanı, NotaBene Yayınları, Ankara.

Ploeg, J. D. (2019). Bir Kez Daha Köylü Üretim Tarzı Üzerine. (Ed. Tayfun Özkaya) , Başka Bir Köylülük Mümkün, Yeniinsan Yayınevi, İstanbul.

Samsun Ticaret ve Sanayi Odası (STSO). (2016). Samsun Iktisadi Rapor 2016, http://www.samsuntso. org.tr/yayinlar/iktisadi-rapor, Samsun.

Sayılı M. ve Yulafçı A. (2015). Samsun İlinde Kırsal Göç Yaşanan Köylerin Genel Özellikleri ve Göçün Köyler Üzerindeki Etkileri. Marmara Coğrafya Dergisi, Sayı:32, 403-426.

T.C. Samsun Ill Özel İdaresi. (2011). Samsun Illi Tarım Master Planı. https://samsun.tarimorman.gov.tr/ Belgeler/Yayinlar/Tarimsal_strateji/masterplan_taslak\%2025082011.pdf.

T.C. Samsun Valiliği Çevre ve Şehircilik il Müdürlügüu. (2018). Samsun Ili 2018 Yllı Çevre Durum Raporu. https://webdosya.csb.gov.tr/db/ced/icerikler/samsun_-cdr2018-20200117095833.pdf, Samsun.

Uzun, A. Ve Demir, Y. (2016). Kentsel Saçaklanmanın Tarım Alanlarına Yayılımının Uydu Görüntüleri Yardımıyla Belirlenmesi: Samsun Örneği. Anadolu Tarım Bilimleri Dergisi, 31, 408-416.

Wolf, E. R. (2000). Köylüler, Çev. Abdulkerim Sönmez, İmge Yayınevi, Ankara.

World Development Report 2008 (2007). Agriculture for Development. Washington DC: TheWorld Bank. Yılmaz, C. ve Zeybek, H. İ. (2016). Samsun Coğrafyası, Canik Belediyesi Kültür Yayınları, Samsun.

Yılmaz E. ve Kaya, M. (2017). Neopopülizm ve Köylülük: İki Köy Örneği. VIII. Ulusal Sosyoloji Kongresi Bildiriler Kitabı, Ankara, 599-604.

Zeybek, H. İ. (2006). Sosyo-Ekonomik Kriterlere Göre Samsun İlinin Karadeniz Coğrafi Bölgesi ve Türkiye'deki Yeri. Geçmişten Geleceğe Samsun Sempozyumu, http://kultur.samsun.bel.tr/ samsem2006/doc/029.pdf, 503-520. 
